Bu makaleye atıfta bulunmak için/To cite this article:

AKKURT ÇAĞLAR, A. (2021). Öğretmen Adaylarının Şarkı Sözlerindeki Coğrafya Kavramlarını Anlama Düzeyi

ve Kavram Yanılgıları. Atatürk Üniversitesi Sosyal Bilimler Enstitüsü Dergisi, 25 (4), 1420-1439.

\title{
Öğretmen Adaylarının Şarkı Sözlerindeki Coğrafya Kavramlarını Anlama Düzeyi ve Kavram Yanılgıları
}

\begin{abstract}
Ayşe AKKURT ÇAĞLAR ${ }^{(*)}$
Öz: Bu çalışmanın amacı sosyal bilgiler öğretmen adaylarının şarkı sözlerindeki bazı coğrafya kavramlarını anlama düzeyleri ve kavram yanılgılarını ortaya koymaktır. Bu çalışmada 2018 yılının popüler şarkılarından 14 şarkı seçilmiş ve bu şarkıların sözlerinde geçen kırağı, karadelik, iklim, sıcaklık, eksen, büyükşehir, krater, güneş tutulması, ay tutulması, ada, yıldız, şehir, rüzgâr, gelgit, ova, yayla olmak üzere 16 kavram incelenmiştir. Çalışmada betimsel tarama yöntemi kullanılmıştır. Çalışma grubu Sosyal Bilgiler Öğretmenliği üçüncü sınıfina devam eden 60 ögretmen adayından oluşmaktadır. Verilerin toplanmasında araştırmacı tarafindan geliştirilen anket kullanılmıştır. Veriler Excel programında analiz edilerek frekans ve yüzde değerleri hesaplanarak tablolar oluşturulmuştur. Sosyal bilgiler ögretmen adaylarının kavramlara verdikleri cevaplar doğru algılama, sinırlı algılama, yanlış algılama ve cevapsı kategorilerine göre değerlendirilmiştir. Çalışmanın sonucunda öğretmen adaylarının az ya da çok şarkı sözlerinde duydukları ve bildikleri, coğrafya kavramlarını anlama düzeyleri incelendiğinde ise pek çok kavramı doğru bilmedikleri ve kavram yanılgıları yaşadıkları belirlenmiştir.
\end{abstract}

Anahtar Kelimeler: Sosyal bilgiler öğretmen adayı, coğrafya, kavram, kavram yanılgısı, şarkı sözü.

\section{Teacher Candidates' Level of Understanding and Misconceptions of Geographic Concepts Used in Song Lyrics}

\begin{abstract}
This study aims to examine the social studies teacher candidates' level of understanding and misconceptions of some geography concepts used in the song lyrics. In this study, 14 songs were selected from the popular songs of 2018, and 16 concepts were selected from these songs, including rime, black hole, climate, temperature, axis, metropolitan, crater, solar eclipse, lunar eclipse, island, star, city, wind, tide, plain, and plateau. Descriptive survey method was used in the study. The study group consists of 60 preservice social studies teachers who were third year students in the social studies education program of the educational faculty. A questionnaire developed by the researcher was used to collect the data. The data were analyzed in the Excel program and the tables were created by calculating the frequency and percentage values. The answers given by the social studies teacher candidates to the concepts were evaluated according to the categories of correct understanding, limited understanding, misunderstanding
\end{abstract}

${ }^{*}$ Dr. Öğr. Üyesi, Gaziosmanpaşa Üniversitesi Eğitim Fakültesi Türkçe ve Sosyal Bilimler Eğitimi Bölümü (e-posta: ayse.akkurt@gop.edu.tr) (D) ORCID ID. https://orcid.org/0000-0002-5424-6802

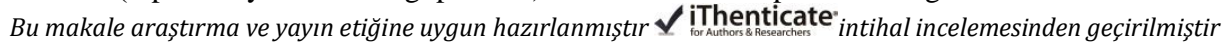


and no answer. As a result of the study, when the pre-service teachers' level of understanding of the concepts of geography they heard and knew more or less in the song lyrics was examined, it was determined that they did not know many concepts correctly and they have misconceptions about them.

Keywords: Social studies teacher candidates, geography, concept learning, misconceptions, song lyrics.

Makale Geliş Tarihi: 23.10.2021

Makale Kabul Tarihi: 21.12.2021

DOI: 10.53487/ataunisosbil.1013861

\section{Giriş}

Doğduğu günden itibaren çevresini keşfetmeye çalışan, merak eden, sorgulayan, çevresinden etkilenen ve çevresini etkileyen insanoğlunun gündelik hayatı coğrafi fenomenlerle kuşatılmıştır. Fen bilimlerinde, sosyal bilimlerde, sanat ve edebiyatta coğrafya vardır. Coğrafya meskenin şeklini etkilediği kadar, siyaseti, sanatı, şairi ve besteciyi de etkilemektedir. Gerçekten de, bu sanatçılar eserlerinde, ya geçmişe özlemi, ya bir kahramanlık öyküsünü, ya da doğal güzellikleri, doğa olaylarl ve doğaya özlemi; bir hüzün, bir sevinç, bir heyecan veya bir bedbin ruh hâli duygularlyla birleştirerek şiirlerde-şarkılarda terennüm etmişlerdir (Doğanay, 2005). Şiirlerde ve şarkı sözlerinde sanatçılar duygularını yeryüzündeki herhangi bir nesne veya coğrafi olayın doğrudan anlamı ya da mecaz anlamı üzerinden aktarmakta, coğrafyayla ilgili çeşitli kavramlara sözlerinde sıkça yer vermektedir.

Sen geldiğin zaman, mevsim bahard1 Şimdi sen gidiyorsun mevsim sonbahar

Geçsin günler, haftalar

Aylar, mevsimler, yıllar

Zaman sanki bir rüzgâr

Yukarıdaki şarkı sözünde olduğu gibi esas teması coğrafya olan sözler görülebildiği gibi (Doğanay, 2005) bazen bir coğrafi olayın şarkı sözünde metaforik bir anlam kazandığı da görülmektedir. Sezen Aksu 'Zelzele' şarkı sözünde zelzele bu metaforlar arasindadır (Paker, 2008).

....Kubbeler hu çeker

Kullar sallanır ...

Evler secde etmiş hey hey...

Odalar hu çeker holler sallanır ...

Zelzele, Firuze, 1982

Şarkılar için hazırlanmış video kliplerde de bazen şarkı sözlerindeki coğrafi olay ve kavramlara yer verildiği görülebilmektedir. Örneğin: Buray - Aşk Bitsin video klibinde 
(Buray, 2019), şark1 sözlerinde (Ançel, 2018, parça 1) geçen güneş ve ay tutulmasılyla birlikte klipte, güneş ve ay tutulmasıyla ilgili görsellere de yer verilmiştir.

Sanatçı, şiir, söz ve mekânın karşılıklı ilişkisi ortaya koyan çalışmalarda (Yıldırım, 1994; Yivli, 2009; Yılmaz, 2017; Şimşek, 2018) göstermiştir ki sanat coğrafyadan, coğrafi mekândan ayrı düşünülemez. Coğrafi mekân "şairin duygu, hayal ve fikirlerinin hareket ve dayanak noktalarından biridir" (Özarslan, 2010). Şiirlerdeki, şarkı sözlerindeki çeşitli unsurlar, hisler, öyküler de tıpkı coğrafyanın insan karakteri üzerindeki etkisi, iklimin yetiştirilen tarım ürünü üzerindeki etkisi gibi coğrafyayla bağlantılıdır. Bununla birlikte insan müzik ilişkisi doğum öncesinden başlayıp insan yaşamının neredeyse her evresinde var olan, çeşitlenen bir olgudur (Yıldız, 2006; Uçan, 1994). İnsanlar her yaşta müzikle ilgilenmektedirler. Özden (2010) üniversite öğrencilerinin popüler kültür ve popüler müzikle ilgili görüşlerini incelediği çalışmasında, öğrencilerin en çok kullandıkları kitle iletişim araçlarının televizyon ve internet olduğunu bunlardan da daha çok eğlence ve müzik indirme amaçlı yararlandıklarını ortaya koymuştur. Çalışmada öğrencilerin çok sık müzik dinledikleri müzik indirdikleri, beğendikleri popüler müzik sanatçısıyla ilgili klipleri çok sık takip ettikleri ortaya çıkarılmışıtır.

Müzik öğrencilerin gündelik hayatının içerisindedir. Bu bağlamda öğrencilerin ister istemez şarkı sözlerinin içerisinde geçen coğrafya kavramlarını işittikleri, şarkı sözleriyle kavramları dile getirdikleri düşünülebilir. Turan (2002) öğrenilen bilgi ve kavramların gündelik hayatta kullanılmasının kalııllı̆̆ arttırabileceğini belirtmiştir. Gündelik hayatta eğlenmek için otobüste, spor yaparken, dinlenirken pek çok yerde dinlenilen şarkı sözlerindeki coğrafya kavramları, öğretmenlerin kavramlarla ilgili dikkat çekme ve örnek olması açısından öğretimde kullanılabilir.

Kavram öğretimi coğrafya öğretiminde de önemli bir yere sahiptir. Bu nedenle yıllardır coğrafya ile ilgili kavram yanılgılarının olduğu pek çok çalışma yapılmıştır (Bozkurt ve Cansüngü, 2002; Turan, 2002; Başıüyük vd., 2004; Sever, 2005; Alkış, 2006; Kızılçaoğlu, 2009; Demirkaya ve Karacan, 2016; Ertaş, 2019; Kuzey ve Değirmenci, 2019). İlk çalışmalardan günümüze kadar onlarca çalışma yapıllmasına rağmen kavramlar halen karıştırılmaktadır (Akış ve Kaya, 2018; Kaya ve Bozyiğit, 2019). Bu durum coğrafya eğitimcilerinin üzerinde düşünmesi, çözümü için çalışması gereken konulardandır. 4. ve 5. sınıf ders kitaplarında bile çok fazla coğrafya kavramı olduğu görülmektedir (Alkış, 2005; Çetin vd., 2021). Kavramların doğru olarak öğrenilmediği durumlarda bilimsel bilginin öğrenilmesi engellenir ve öğrencilerin konuyu anlaması da zorlaşır (Bozyiğit ve Kaya, 2017).

Coğrafya öğretiminde, öğrenci, öğretmen ve ders kitaplarından kaynaklı kavram yanılgıları yaşanmaktadır. Öğrenci boyutunda; öğrencilerin coğrafyayı soyut bir ders olarak görmeleri, büyük oranda ezber gerektirdiğine inanmaları (Akengin ve Süer, 2011), bazı öğrencilerin coğrafya dersini zor ve bazı konuları sıkıcı olarak görmeleri (Bedir ve Akkurt, 2012) konu ve kavram öğretimini zorlaştırmaktadır. Öğretmen boyutunda; mezun olan kişi öğretmen olacağına göre mesleğe başlar başlamaz alan bilgisi ve pedagojik mesleki formasyon bilgisi açısından donatılmış mı? (Güngördü, 2006) sorusu gündeme gelmektedir. Cin (2010) Öğretmen adaylarına yönelik yürüttüğü 
çalışmasında "Ĕğer öğretmen adaylart yanılgılarla birlikte mezun olup ögretmenlik mesleğine başlarlarsa, ögrencilerine de aynı yanılgıları taşımaları muhtemeldir" demiştir (Cin, 2010). Coğrafya öğretimi süreci temelde öğretmenin konuyu öğretmesi, öğrencinin de konuyu öğrenmesini gerektirir. $\mathrm{Bu}$ nedende coğrafyanın öğrenciler tarafından öğrenilmesi ve coğrafi kavramları doğru olarak öğretilmesi arasında önemli bir bağ vardır (Gülüm, 2010). Yani öğrenciler zaten kavram yanılgısı yaşayabilecekken bunlara birde öğretmen kaynaklı yanılgının eklenmesi coğrafya öğretiminde sorunu büyütmektedir. Bazı coğrafya ders kitaplarında konular işlenirken yanlışlıklar yapıldığı, bazı kavramların yanlış ifade edildiği, görsel zenginliğin sınırlı kaldığı görülmektedir (Coşkun, 2003). Ders kitapları hem alan hem de pedagojik bilgisi olmayan kişiler tarafından hazırlanmış olabilir. Alan ve pedagojik bilgisi yeterli bilim adamları tarafından yazılmış ders kitaplarında içerikler kavram yanılgısına neden olmayacak şekilde düzenlenebilir (Cin, 2010).

Coğrafi kavramların doğru bilinmesi ve kullanılması, yeni öğrenilecek konuların doğru temeller üzerine oturmasında sağlıklı coğrafya öğretiminde önemlidir. İlerde coğrafya öğretecek olan sosyal bilgiler öğretmeni adaylarının gündelik hayatlarının içinde var olan sıkça duydukları, dillerine dolanmış şarkı sözlerindeki coğrafya kavramlarını fark etmeleri, şarkı sözlerini dile getirirken kendilerinin de şarkı sözleri içinde kullandıkları bu kavramları bilmeleri beklenmektedir. Örneğin öğretmen adayı buz kırağı şarkısını (Tilbe, 1995, parça 1) bütün yaz boyunca defalarca dinliyor, şarkı sözlerini ezbere söylüyor yani kırağı kavramını ister istemez kullanıyor. Ancak kırağı nedir? sorusunda kırağıyı bilmiyor veya karıştırıyorsa bu durum coğrafya öğretimi için değerlendirilmesi gereken bir husus olarak görülmüş ve bu çalışmada bu durum değerlendirilmeye çalışılmıştır.

\section{A. Araştırmanın Amacı:}

Araştırmanın amacı sosyal bilgiler öğretmeni adaylarının şarkı sözlerindeki bazı coğrafya kavramlarını anlama düzeyleri ve kavram yanılgılarını ortaya koymaktır.

$\mathrm{Bu}$ çerçevede araştırmanın alt problemleri şu şekildedir:

1. Sosyal bilgiler ögretmen adayları araştırma için seçilen şarkıları ne sıklıkta dinlemişlerdir, şarkıların sözlerini biliyorlar mı?

2. Sosyal bilgiler öğretmen adaylarının seçilen şarkı sözlerinde geçen coğrafya kavramlarını anlama düzeyleri nasıldır?

3. Sosyal bilgiler öğretmen adaylarının seçilen şarkı sözlerinde geçen coğrafya kavramlarına yönelik kavram yanılgıları nelerdir?

\section{YÖNTEM}

A. Araştırma Deseni: $\mathrm{Bu}$ çalışmada betimsel tarama yöntemi kullanılmıştır. $\mathrm{Bu}$ çalışmada öğretmen adaylarının mevcut var olan durumları ortaya koyulmaya çalışılacağı için bu yöntem seçilmiştir. Bilindiği gibi tarama modelleri, geçmişte veya halen var olan bir durumu olduğu şekliyle tasvir etmeye çalışan araştırma yaklaşımlarıdır (Karasar, 1998). 
B. Çalışma Grubu: Araştırmada kolay ulaşılabilir durum örneklemesi kullanılmışıtır. $\mathrm{Bu}$ yöntem araştırmaya hız ve pratik kazandırır (Yıldırım ve Şimşek, 2013). Araştırmacının derslerini yürüttüğü sosyal bilgiler öğretmenliği üçüncü sınıfına devam eden 60 öğretmen adayı çalışma grubunu oluşturmaktadır. Bu öğretmen adaylarının 23'ü erkek 37'si kadındır.

C. Veri Toplama Aracı: Araştırmacı tarafindan oluşturulan ve iki bölümden oluşan anket çalışmanın veri toplama aracını oluşturmaktadır. Anketin birinci bölümünde öğrencilerin cinsiyet, belirlenen şarkıları dinleme durumlarını (ilk defa, bir kere, birkaç kere, defalarca) ve şarkı sözlerini bilip bilmediklerini (evet-hayır) belirlemeye yönelik sorular yer almaktadır. İkinci kısmında ise şarkı sözlerinde geçen 16 kavram açık uçlu olarak sorulmuştur.

D. Verilerin Toplanması Süreci: Bu çalışmada 2018 yılının popüler şarkılarından seçilen 14 şarkı ve bu şarkıların sözlerinde geçen kırağı, karadelik, iklim, sıcaklık, eksen, büyükşehir, krater, güneş tutulması, ay tutulması, ada, yıldız, şehir, rüzgâr, gelgit, ova, yayla olmak üzere 16 kavram incelenmiştir (Tablo 1).

Tablo 1. Uygulama İçin Seçilen Şarkılar ve Şarkı Sözlerindeki Coğrafi Terimler.

\begin{tabular}{lll}
\hline Şarkıcı & Şarkı Adı & Terim \\
\hline Aleyna Tilki & Yalnız Çiçek & İklim \\
Buray & Aşk Bitsin & Güneş Tutulması \\
Buray & Aşk Bitsin & Ay Tutulması \\
Canfeza & Dem & Krater \\
Edis & Buz Kırağı & Kırağı \\
Feride Hilal Akın-İlyas & Şehrin Yolu & Şehir \\
Yalçıntaş & & \\
Gazapizm & Heyecanı Yok & Eksen \\
Gülşen & Delikanlım & Sicaklık \\
İlyas Yalçıntaş & Arzular Arsız & Gelgit \\
Kenan Doğulu & Issız Ada & Ada \\
Kenan Doğulu & Issız Ada & Yıldız \\
Koray Avcı & Bu Dünya Yalan & Yayla \\
Nil Özalp & Büyük Delilik & Karadelik \\
Sıla & Gözlerine Teslimim & Büyük Şehir \\
Soner Sarıkabadayı & Tarifi Zor & Rüzgâr \\
Zara & Dili Ballım & Ova \\
\hline
\end{tabular}

Şarkılar 2018 yılının popüler şarkıları arasından belirlenmiştir. Google arama motorunda "2018 en çok dinlenen şarkılar" başlığında görselleriyle çıkan ilk 20 şarkı, Spotify'da 2018 yazının Türkiye top 10 listesi, yine yılın en fazla dinlenen şarkılarının ilk 100 listesi baz alınarak coğrafya terimlerinin geçtiği şarkılar 14 şarkı seçilmiştir. Bu 
şarkılar; Yalnız Çiçek (Tilbe, 1994, parça 1), Aşk Bitsin (Ançel, 2018, parça 1), Dem (Canfeza, 2018), Buz Kırağ1 (Tilbe, 1995, parça 1), Şehrin Yolu (Yalçıntaş, 2018, parça1), Heyecanı Yok (Gazapizm, 2017, parça 1), Delikanlım (Tilbe, 1994, parça 5), Arzular Arsız (Tilbe, 1995, parça 9), Issız Ada (Doğulu vd., 2018, parça 1), Bu Dünya Yalan (Bağcan, 1972, parça 4), Büyük Delilik (Şehrazat, 2018, parça 1), Gözlerine Teslimim (Gençoğlu, 2012, parça 13), Tarifi Zor (Sarıkabadayı, 2018, parça 2), Dili Ballım (Tilbe, 1996, parça 8).

Veri toplama aracı olan anket sınıf ortamında yüz yüze uygulanmıştır. Öğretmen adayları sınıfta teker teker oturmuşlardır. Daha sonra anketler dağıtılmıştır. Araştırmacı öğrencilere sırasıyla şarkıları dinletmiştir. Öğretmen adaylarından her şarkıdan sonra ankette şarkıya ilişkin bölümü doldurmaları istenmiştir. Son olarak öğretmen adayları açık uçlu sorulan 16 coğrafya kavramını tanımlamışlardır.

E. Veri Analizi: Araştırmanın verileri Excel programında analiz edilerek frekans $(f)$ ve yüzde (\%) değerleri hesaplanmış ve tablolar oluşturulmuştur. Sosyal bilgiler öğretmen adaylarının kavramlarla ilgili verdikleri cevaplarda anlama seviyeleri Kayacan'ın Platten'in (1995) çalışmasından aktardığı dört kategoride değerlendirilmiştir (Kayacan, 2010).

Kategoriler şu şekildedir:

1-Doğru Algılama: Soru ile ilgili bilimsel cevabın bütün yönlerini içeren cevapları içermektedir. Tamamen doğru olan açıklamalardır.

2-Sınırlı Algılama: Geçerli olan bilimsel cevabın bir ya da birkaç yönünü içeren fakat bütün yönlerini belirtmeyen cevapları kapsamaktadır. Kısmen doğru olan algılamalar da bu kategoriye dahil edilmiştir.

3-Yanlış Algılama: Bilimsel bilgilerle tutarlı olmayan ve alternatif açıklamaları içeren öğrenci açıklamaları bu kategoride verilmiştir.

4-Cevapsız: Bu kategori ise öğrencilerin "Bilmiyorum” şeklinde cevap verdikleri ya da boş bıraktıkları cevapları içermektedir. Soruyu aynen tekrarlama, ilgisiz ya da açık olmayan cevaplar da bu kategoride yer almaktadır

Öğrencilerin kavramlarla ilgili cevapları kategorilere göre değerlendirilmiş ve sonuçlara ilişkin frekans $(f)$ ve yüzde $(\%)$ değerleri hesaplanmıştır. Veriler sunulurken katılımcı gizliliğini korumak amacıyla, öğretmen adaylarının ifadeleri Öğretmen-1 (Ö1, Ö2...) şeklinde numaralandırılmış ve bulgular kısmında görüşüne yer verilen öğretmen adayları bu şekilde belirtilmiştir.

\section{Bulgular ve Yorum}

1.Sosyal bilgiler öğretmen adayları araştırma için seçilen şarkıları ne sıklıkta dinlemişlerdir, şarkıların sözlerini biliyorlar mı?

Öğretmen adaylarının çalışmayla ilgili olarak seçilen 14 parçayı dinleyip dinlememe durumları ve bu şarkıların sözlerini bilip bilmeme durumları sorgulanmış verilen cevaplar Tablo 2 ve 3 'te gösterilmiştir. 
Öğretmen Adaylarının Şarkı Sözlerindeki Coğrafya Kavramlarını Anlama Düzeyi ve Kavram Yanılgıları

Tablo 2. Sosyal Bilgiler Öğretmen Adaylarının Seçilmiş Şarkıları Dinleme Durumlarının Dağılımı.

\begin{tabular}{|c|c|c|c|c|c|}
\hline Şarkı Adı & & $\begin{array}{l}\text { İlk defa } \\
\text { duydum }\end{array}$ & $\begin{array}{l}\text { Bir kere } \\
\text { dinledim }\end{array}$ & $\begin{array}{l}\text { Birkaç } \\
\text { kere } \\
\text { dinledim }\end{array}$ & $\begin{array}{l}\text { Defalarca } \\
\text { dinledim }\end{array}$ \\
\hline \multirow[t]{2}{*}{ Buz Kırağ1 } & f & 15 & 4 & 10 & 31 \\
\hline & $\%$ & 25.0 & 6.7 & 16.7 & 51.7 \\
\hline \multirow[t]{2}{*}{ Yalnız Çiçek } & $\mathrm{f}$ & 0 & 1 & 19 & 40 \\
\hline & $\%$ & 0 & 1.7 & 31.7 & 66.7 \\
\hline \multirow[t]{2}{*}{ Delikanlım } & $\mathrm{f}$ & 6 & 2 & 13 & 39 \\
\hline & $\%$ & 10.0 & 3.3 & 21.7 & 65.0 \\
\hline \multirow[t]{2}{*}{ Heyecanı Yok } & $\mathrm{f}$ & 1 & 3 & 17 & 39 \\
\hline & $\%$ & 1.7 & 5.0 & 28.3 & 65.0 \\
\hline \multirow[t]{2}{*}{ Şehrin Yolu } & $\mathrm{f}$ & 6 & 4 & 11 & 39 \\
\hline & $\%$ & 10.0 & 6.7 & 18.3 & 65.0 \\
\hline \multirow[t]{2}{*}{ Tarifi Zor } & $\mathrm{f}$ & 9 & 6 & 12 & 33 \\
\hline & $\%$ & 15.0 & 10.0 & 20.0 & 55.0 \\
\hline \multirow[t]{2}{*}{ Bu Dünya Yalan } & $\mathrm{f}$ & 16 & 7 & 16 & 21 \\
\hline & $\%$ & 26.7 & 11.7 & 26.7 & 35.0 \\
\hline \multirow[t]{2}{*}{ Aşk Bitsin } & $\mathrm{f}$ & 17 & 5 & 21 & 17 \\
\hline & $\%$ & 28.3 & 8.3 & 35.0 & 28.3 \\
\hline \multirow[t]{2}{*}{ Büyük Delilik } & $\mathrm{f}$ & 51 & 4 & 1 & 4 \\
\hline & $\%$ & 85.0 & 6.7 & 1.7 & 6.7 \\
\hline \multirow[t]{2}{*}{ Gözlerine Teslimim } & $\mathrm{f}$ & 38 & 4 & 8 & 10 \\
\hline & $\%$ & 63.3 & 6.7 & 13.3 & 16.6 \\
\hline \multirow[t]{2}{*}{ Dem } & $\mathrm{f}$ & 47 & 5 & 1 & 7 \\
\hline & $\%$ & 78.3 & 8.3 & 1.7 & 11.7 \\
\hline \multirow[t]{2}{*}{ Issiz Ada } & $\mathrm{f}$ & 22 & 8 & 20 & 10 \\
\hline & $\%$ & 36.7 & 13.3 & 33.3 & 16.7 \\
\hline \multirow[t]{2}{*}{ Arzular Arsiz } & $\mathrm{f}$ & 39 & 4 & 9 & 8 \\
\hline & $\%$ & 65.0 & 6.7 & 15.0 & 13.3 \\
\hline \multirow[t]{2}{*}{ Dili Ballım } & $\mathrm{f}$ & 49 & 5 & 1 & 5 \\
\hline & $\%$ & 81.7 & 8.3 & 1.7 & 8.3 \\
\hline
\end{tabular}

Tablo 2 incelendiğinde sosyal bilgiler öğretmen adaylarının en çok dinledikleri şarkı Yalnız Çiçek ( $\mathrm{f}=40, \% 66.7$ ), en çok ilk defa duyduklarını belirttikleri şarkı ise Büyük Delilik ( $\mathrm{f}=51, \% 85)$ şarkısıdır. Öğretmen adaylarının çoğunluğunun toplam 7 şarkıyı (Buz Kırağı, Yalnız Çiçek, Delikanlım, Heyecanı Yok, Şehrin Yolu, Tarifi Zor, Bu Dünya Yalan) defalarca dinlediği, 6 şarkıyı ilk defa duyduğu (Büyük Delilik, Gözlerine 
Teslimim, Dem, Issız Ada, Arzular Arsız, Dili Ballım), 1 şarkıyı (Aşk Bitsin) ise birkaç kere dinledikleri görülmektedir.

Tablo 3. Öğretmen Adaylarının Seçilmiş Şarkıların Sözlerini Bilip Bilmeme Durumlarının Dağılımı.

\begin{tabular}{llll|llll}
\hline Şarkı Adı & & Evet & Hayır & Şarkı Adı & & Evet & Hayır \\
\hline Buz Kırağı & $\mathrm{f}$ & 35 & 25 & Aşk Bitsin & $\mathrm{f}$ & 40 & 20 \\
& $\%$ & 58.3 & 41.7 & & $\%$ & 66.7 & 33.3 \\
Büyük Delilik & $\mathrm{f}$ & 4 & 56 & Issız Ada & $\mathrm{f}$ & 25 & 35 \\
& $\%$ & 6.7 & 93.3 & & $\%$ & 41.7 & 58.3 \\
Yalnız Çiçek & $\mathrm{f}$ & 55 & 5 & Şehrin Yolu & $\mathrm{f}$ & 43 & 17 \\
& $\%$ & 91.7 & 8.3 & & To & 71.7 & 28.3 \\
Delikanlım & $\mathrm{f}$ & 52 & 8 & Tarifi Zor & $\mathrm{f}$ & 42 & 18 \\
& $\%$ & 86.7 & 13.3 & & $\%$ & 70 & 30 \\
Heyecanı Yok & $\mathrm{f}$ & 55 & 5 & Arzular Arsız & $\mathrm{f}$ & 16 & 44 \\
& $\%$ & 91.7 & 8.3 & & $\%$ & 26.7 & 73.3 \\
Gözlerine & $\mathrm{f}$ & 15 & 45 & Dili Ballım & $\mathrm{f}$ & 4 & 56 \\
Teslimim & $\%$ & 25 & 75 & & $\%$ & 6.7 & 93.3 \\
Dem & $\mathrm{f}$ & 6 & 54 & Bu Dünya & $\mathrm{f}$ & 34 & 26 \\
& $\%$ & 10 & 90 & Yalan & $\%$ & 56.7 & 43.3 \\
\hline
\end{tabular}

Tablo 3 incelendiğinde sosyal bilgiler öğretmen adaylarının bütün şarkı sözlerini az ya da çok bildikleri görülmektedir. Şarkı sözlerini en fazla bildiklerini belirttikleri şarkı sözü Yalnız Çiçek ( $\mathrm{f}=55, \% 91.7)$ ve Heyecanı Yok ( $\mathrm{f}=55, \% 91.7)$, en az bildikleri ise Büyük Delilik ( $\mathrm{f}=56, \% 93.3)$ ve Dili Ballım ( $\mathrm{f}=56, \% 93.3$ ) şarkı sözleridir. Öğretmen adaylarının çoğunluğunun sözlerini bildiğini belirttikleri toplam 8 şarkı bulunmaktadır. Buz Kırağı, Aşk Bitsin, Yalnız Çiçek, Delikanlım, Heyecanı Yok, Şehrin Yolu, Tarifi Zor, Bu Dünya Yalan şarkılarının sözleri öğretmen adaylarının çoğunluğu bildiğini belirtmiştir. 6 şarkının sözlerinin ise öğretmen adayları tarafından daha az bilindiği görülmektedir. Büyük Delilik, Gözlerine Teslimim, Dem, Issız Ada, Arzular Arsız, Dili Ballım şarkılarının sözlerinde sözleri bilmeyenlerin oranlarının daha yüksek olduğu görülmektedir.

2. Sosyal bilgiler öğretmen adaylarının seçilen şarkı sözlerinde geçen coğrafya kavramlarını anlama düzeyleri nasıldır?

Sosyal bilgiler öğretmen adaylarının seçilen şarkı sözlerinde geçen coğrafya kavramlarına verdikleri cevaplar doğru algılama, sınırlı algılama, yanlış algılama ve cevapsız kategorilerine göre değerlendirilerek aşağıdaki tabloda gösterilmiştir (Tablo 4).

Tablo 4. Sosyal Bilgiler Öğretmen Adaylarının Kavramlara İlişkin Cevaplarını Dağılımı.

\begin{tabular}{llllll}
\hline Kavramlar & & $\begin{array}{l}\text { Doğru } \\
\text { Algılama }\end{array}$ & $\begin{array}{l}\text { Sinırlı } \\
\text { Algılama }\end{array}$ & $\begin{array}{l}\text { Yanlış } \\
\text { Algılama }\end{array}$ & Cevapsız \\
\hline Kıră̆ı & f & 12 & 9 & $\mathbf{2 1}$ & 18 \\
& $\%$ & 20 & 15 & $\mathbf{3 5}$ & 30
\end{tabular}


Öğretmen Adaylarının Şarkı Sözlerindeki Coğrafya Kavramlarını Anlama Düzeyi ve Kavram Yanılgıları

\begin{tabular}{|c|c|c|c|c|c|}
\hline \multirow[t]{2}{*}{ Karadelik } & $\mathrm{f}$ & 7 & 7 & 16 & 30 \\
\hline & $\%$ & 11.7 & 11.7 & 26.6 & 50 \\
\hline \multirow[t]{2}{*}{ Íklim } & f & 8 & 14 & 24 & 14 \\
\hline & $\%$ & 13.4 & 23.3 & 40 & 23.3 \\
\hline \multirow[t]{2}{*}{ Sicaklık } & $\mathrm{f}$ & 13 & 8 & 13 & 26 \\
\hline & $\%$ & 21.6 & 13.3 & 21.6 & 43.3 \\
\hline \multirow[t]{2}{*}{ Eksen } & $\mathrm{f}$ & 1 & 2 & 25 & 32 \\
\hline & $\%$ & 1.7 & 3.3 & 41.7 & 53.3 \\
\hline \multirow[t]{2}{*}{ Büyükşehir } & $\mathrm{f}$ & 8 & 14 & 26 & 12 \\
\hline & $\%$ & 13.4 & 23.3 & 43.3 & 20.0 \\
\hline \multirow[t]{2}{*}{ Krater } & f & 13 & 9 & 17 & 21 \\
\hline & $\%$ & 21.7 & 15 & 28.3 & 35 \\
\hline \multirow[t]{2}{*}{ Güneş Tutulması } & $\mathrm{f}$ & 24 & 6 & 8 & 22 \\
\hline & $\%$ & 40.0 & 10.0 & 13.3 & 36.7 \\
\hline \multirow[t]{2}{*}{ Ay Tutulmast } & f & 12 & 3 & 21 & 24 \\
\hline & $\%$ & 20.0 & 5.0 & 35.0 & 40.0 \\
\hline \multirow[t]{2}{*}{$A d a$} & f & 21 & 13 & 11 & 15 \\
\hline & $\%$ & 35.0 & 21.7 & 18.3 & 25.0 \\
\hline \multirow[t]{2}{*}{ Ylldiz } & $\mathrm{f}$ & 2 & 9 & 27 & 22 \\
\hline & $\%$ & 3.3 & 15.0 & 45.0 & 36.7 \\
\hline \multirow[t]{2}{*}{ Şehir } & f & 29 & 4 & 12 & 15 \\
\hline & $\%$ & 48.3 & 6.7 & 20.0 & 25.0 \\
\hline \multirow[t]{2}{*}{ Rüzgâr } & f & 7 & 9 & 19 & 25 \\
\hline & $\%$ & 11.6 & 15.0 & 31.7 & 41.7 \\
\hline \multirow[t]{2}{*}{ Gelgit } & $\mathrm{f}$ & 2 & 22 & 20 & 16 \\
\hline & $\%$ & 3.3 & 36.7 & 33.3 & 26.7 \\
\hline \multirow[t]{2}{*}{ Ova } & f & 15 & 17 & 9 & 19 \\
\hline & $\%$ & 25.0 & 28.3 & 15.0 & 31.7 \\
\hline \multirow[t]{2}{*}{ Yayla } & $\mathrm{f}$ & 20 & 23 & 4 & 13 \\
\hline & $\%$ & 33.3 & 38.3 & 6.7 & 21.7 \\
\hline
\end{tabular}

Tablo 4 incelendiğinde sosyal bilgiler öğretmen adaylarının çoğunluğunun eksen $(\mathrm{f}=32, \% 53.3)$, karedelik $(\mathrm{f}=30, \% 50)$, sicaklık $(\mathrm{f}=26, \% 43.3)$, rüzgar $(\mathrm{f}=25, \% 41.7)$, ay tutulması ( $\mathrm{f}=24, \% 40)$, krater $(\mathrm{f}=21, \% 35)$, ova $(\mathrm{f}=19, \% 31.7)$ kavramlarını cevapsiz bıraktıkları görülmektedir. En fazla cevapsız bırakılan kavramın ise eksen kavramı olduğu görülmektedir. En fazla cevapsız bırakılan eksen kavramı öğretmen adaylarının doğru algılama kategorisinde de en az paya sahip olan kavramdır. Öğretmen adaylarından yalnızca 1 kişi eksen kavramına doğru cevabı vermiştir. Doğru algılama kategorisinde en çok orana sahip kavramlar şehir ( $\mathrm{f}=29, \% 48.3)$, ada $(\mathrm{f}=21, \% 35)$ ve güneş tutulması ( $\mathrm{f}=24, \% 40)$ kavramlarının olduğu görülmektedir. Öğretmen adaylarının doğru algılama kategorisinden en çok paya sahip olan kavram 16 kavram içerisinde şehir kavramıdır. Sınırlı algılama kategorisinde en fazla paya sahip kavramlar ise yayla $(\mathrm{f}=23, \% 38.3)$, gelgit $(\mathrm{f}=21, \% 35)$ ve ova $(\mathrm{f}=17, \% 28.3)$ kavramlarıdır. Yanlış algılama kategorisinde ise yıldız ( $\mathrm{f}=27, \% 45)$, büyükşehir $(\mathrm{f}=26, \% 43.3)$, iklim $(\mathrm{f}=24, \% 40)$, kırağ 
( $\mathrm{f}=21, \% 35)$ kavramlarının en yüksek paya sahip olduğu görülmektedir. Öğretmen adaylarının verdiği cevaplara göre en fazla yanlış anlaşılan kavramın yıldız kavramı olduğu ortaya çıkmıştır.

Kırağı kavramına sosyal bilgiler öğretmen adaylarının çoğunluğu yanlış algılama kategorisinde cevaplar vermiştir. İkinci sırada ise çoğunluğu cevapsız bırakmıştır. Doğru algılama kategorisinde öğretmen adaylarının \%20'si cevap vermişlerdir. \%15 ' $\mathrm{i}$ ise sınırlı algılama kategorisinde cevap vermiştir. Buna göre öğretmen adaylarının yanlış anlayan ve cevapsız kategorisindeki toplam \%65'inin kırağı kavramını ya hiç bilmediği ya da yanlış bildiği görülmektedir.

Öğretmen adaylarının kırağı ile ilgili bazı örnek ifadeleri:

"Havanın soğuk olduğu zamanlarda bitkilerin yaprakları üzerindeki su tanecikleri" (Ö8).

"Sıcaklı̆̆l 0 derecenin altına düşmüşs soğuk havadır" (Ö47).

Karadelik kavramını sosyal bilgiler öğretmenlerinin çoğunluğunun (\%50) cevapsız bıraktığı görülmektedir. İkinci sırada ise çoğunluk yanlış algılama kategorisindedir. Karadelik kavramını öğretmen adaylarının yalnızca \%11.7'sinin doğru anladığı görülmektedir. Yine sınırlı algılama kategorisinde de \%11.7'lik bir oranın olduğu ortaya çıkmıştır. Cevapsız ve yanlış algılama kategorisinde toplam \%76.6 gibi büyük bir oranın olduğu öğretmen adaylarının bu kavramı anlama düzeylerinin oldukça düşük olduğu görülmektedir.

Öğretmen adaylarının karadelik ile ilgili bazı örnek ifadeleri:

"Volkanik olaylarda volkan patlamasıly oluşan çukurluk” (Ö1).

"Kendisine yaklaşan her şeyi içine çeker" (Ö3).

İklim kavramına sosyal bilgiler öğretmen adaylarının çoğunluğu yanlış algılama kategorisinde cevaplar vermiştir. Öğretmen adaylarının \%23.3 ise cevapsız kategorisinde yine \%23.3'ünün sinırlı algılama kategorisinde cevaplar verdiği görülmüştür. Bu kavrama doğru algılama kategorisinde cevap verenlerin oranı \%13.4 ile en düşük orandır. Yanlış algılama ve cevapsız kategorisinde toplam 63.3'lük bir oran olduğu iklim kavramını öğretmen adaylarının anlama düzeylerinin düşük olduğu görülmektedir.

Öğretmen adaylarının iklim ile ilgili bazı örnek ifadeleri:

"Dünyanın eksen eğikliği ile güneş ışınlarının geliş açısı ile yaz, kış, sonbahar, ilkbahar" (Ö7).

“Sicaklık bitki örtüsü gibi etkenlerin genel adı” (Ö37).

Sıcaklık kavramını sosyal bilgiler öğretmen adaylarının çoğunluğunun \%43.3'ünün cevapsız bıraktığı görülmektedir. İkinci sırada çoğunluğun bulunduğu kategoriler ise \%21.6 yanlış algılama ve doğru algılama kategorileridir. Öğretmen adaylarının \%13.3’ü ise sınırlı algılama kategorisinde cevap vermiştir. Cevapsız ve yanlış algılama kategorisinde toplam \%64.9'lük bir oran olduğu sicaklık kavramına ilişkin öğretmen adaylarının anlama düzeylerinin düşük olduğu ortaya çıkmıştır.

Öğretmen adaylarının sıcaklık ile ilgili bazı örnek ifadeleri:

"Hava durumu belli derecenin üzerindeyse bu slcaklıktır” (Ö2).

"Bir kaynaktan ısının yayılmasına denir” (Ö44). 
Eksen kavramını sosyal bilgiler öğretmen adaylarının çoğunluğunun \%53.3'ünün cevapsız bıraktığ 1 görülmektedir. İkinci sırada çoğunluğun bulunduğu kategori ise $\% 41.7$ ile yanlış algılama kategorisidir. Kavrama ilişkin öğretmen adaylarının \%3.3'ü ise sınırlı algılama \%1.7'si ise doğru algılama kategorisinde cevap vermiştir. Cevapsız ve yanlış algılama kategorisinde toplam \%95 gibi oldukça yüksek bir oran olduğu sıcaklık kavramına ilişkin öğretmen adaylarının anlama düzeylerinin oldukça düşük olduğu ortaya çıkmıştır.

Öğretmen adaylarının eksen ile ilgili bazı örnek ifadeleri:

“Dünyanın kendi etrafinda dönmesi kendi ekseni etrafinda dönmesidir” (Ö18).

“Dünyayı enlemesine olarak kesen hayali çizgilerdir” (Ö 23).

Büyükşehir kavramına öğretmen adaylarının çoğunluğu yanlış algılama (\%43.3) kategorisinde cevap vermişlerdir. En fazla ikin cevap kategorisi ise sınırlı algılamadır. Öğretmen adaylarının \%20'si cevapsız, \%13.4’ü doğru algılama kategorisinde cevap vermişlerdir. Cevapsız ve yanlış algılama kategorisinde toplam \%63.3 oranında cevap olduğu sosyal bilgiler öğretmen adaylarının çoğunluğunun büyükşehir kavramını anlama düzeylerinin düşük olduğu görülmüştür.

Öğretmen adaylarının büyükşehir ile ilgili bazı örnek ifadeleri:

"Belediye olan yerleşim yeri" (Ö2).

"5000 den fazla insanın yaşadiğ yerdir” (Ö3).

Krater kavramını sosyal bilgiler öğretmen adaylarının çoğunluğunun (\%35) cevapsız bıraktığı görülmektedir. İkinci sırada çoğunluğun bulunduğu kategori ise \%28.3 ile yanlış algılama kategorisidir. Kavrama ilişkin öğretmen adaylarının \%21.7'si doğru algılama, \%15'i ise sınırlı algılama kategorisinde cevap vermiştir. Cevapsız ve yanlış algılama kategorisinde toplam \%63,3 gibi bir oran olduğu krater kavramına ilişkin öğretmen adaylarının anlama düzeylerinin düşük olduğu ortaya çıkmıştır.

Öğretmen adaylarının krater ile ilgili bazı örnek ifadeleri:

"Geçirimli taşlar” (Ö37).

“Volkanik arazilerde volkanın patlayıp çevresine attı̆̆ taşlar” (Ö25).

Güneş tutulması kavramına sosyal bilgiler öğretmen adaylarının çoğunluğu doğru algılama (\%40) kategorisinde cevap vermişlerdir. Öğretmen adaylarının \%36.7’ si cevapsız, , \%13.3'ünün yanlış algılama, \%21.7'sinin sınırlı algılama kategorisinde cevap verdiği görülmüştür. Güneş tutulmasına ilişkin öğretmen adaylarının orta düzeyde anlama düzeylerinin olduğu görülmüştür.

Öğretmen adaylarının güneş tutulması ile ilgili bazı örnek ifadeleri:

"Güneşle Dünyanın arasına Ay geldiği zaman güneş tutulması gerçekleşir" (Ö12).

"Güneşin Ay ve Dünya'nın ortasında kalmasıdır" (Ö19).

Ay tutulması kavramını sosyal bilgiler öğretmen adaylarının çoğunluğunun (\%40) cevapsız bıraktığı görülmektedir. Yine sorulara öğretmen adaylarının \%35'inin yanlış algılama, \%20'sinin doğru algılama, \%5 'inin sınırlı algılama kategorisinde cevap verdikleri görülmüştür. Cevapsız ve yanlış algılama kategorisinde toplam \%75 gibi bir oran olduğu bu kavrama ilişkin öğretmen adaylarının anlama düzeylerinin düşük olduğu görülmüştür.

Öğretmen adaylarının ay tutulması ile ilgili bazı örnek ifadeleri: 
"Güneşle Ay arasına Dünya girdiği zaman ay tutulması gerçekleşir" (Ö22).

Ayın Güneş ve Dünya'nın arasında kalmasıdır" (Ö52).

Ada kavramına öğretmen adaylarının çoğunluğu doğru algılama (\%35) kategorisinde cevap vermişlerdir. Öğretmen adaylarının \%25'inin cevapsız, \%21.7'sinin sinırlı algılama, \%18.3'ünün yanlış algılama kategorisinde cevap verdiği görülmüştür. Doğru algılama ve sınırlı algılama kategorisinde toplam $\% 56.7$ gibi bir oran olduğu ada kavramına ilişkin öğretmen adaylarının anlama düzeylerinin yüksek olduğu ortaya çıkmıştır.

Öğretmen adaylarının ada ile ilgili bazı örnek ifadeleri:

“Deniz üzerinde kopmuş kaya parçasına denir"(Ö17).

“Alüvyon malzemelerle suyun getirdiği taş, toprak gibi malzemelerin çoğalmasıyla birikir" (Ö34).

Yıldız kavramı da sosyal bilgiler öğretmenlerinin doğru algılama kategorisinde en az payı olan kavramlardan biridir. Yalnız 2 öğretmen adayının doğru kategoride cevap verdiği görülmektedir. Yıldız kavramına çoğunlukla (\%45) yanlış cevap verildiği görülmektedir. Öğretmen adaylarının \%36.7'si cevapsız, \%15'i sınırlı algılama kategorisinde cevap vermişlerdir. Cevapsız ve yanlış algılama kategorisinde toplam \%81.7 gibi bir oran olduğu bu kavrama ilişkin öğretmen adaylarının anlama düzeylerinin düşük olduğu görülmüştür.

Öğretmen adaylarının yıldız ile ilgili bazı örnek ifadeleri:

"Uzaydaki meteor parçalarıdır" (Ö28).

"Samanyolundaki göktaşlarıdır" (Ö23).

Şehir kavramına öğretmen adaylarının çoğunluğu doğru algılama (\%48.3) kategorisinde cevap vermişlerdir. Öğretmen adaylarının \%25'inin cevapsız, \%20'sinin yanlış algılama, \%6.7'sinin sınırlı algılama kategorisinde cevap verdiği görülmüştür. Doğru algılama ve sınırlı algılama kategorisinde toplam $\% 55$ gibi bir oran olduğu ortaya çıkmıştır.

Öğretmen adaylarının şehir ile ilgili bazı örnek ifadeleri:

"2000 fazla 5000 az yerleşkelere şehir denir" (Ö3).

"Zamanın geçmesiyle insanların toplanması meskenler yapması" (Ö4).

Rüzgâr kavramını sosyal bilgiler öğretmen adaylarının çoğunluğunun (\%41.7) cevapsız bıraktı̆̆ görülmektedir. Yine sorulara öğretmen adaylarının \%31.7'sinin yanlış algılama, \%15'inin sınırlı algılama, \%11.6'sının doğru algılama kategorisinde cevap verdikleri görülmüştür. Cevapsız ve yanlış algılama kategorisinde toplam \% 73.4 gibi bir oran olduğu görülmüştür.

Öğretmen adaylarının rüzgâr ile ilgili bazı örnek ifadeleri: (Ö39).

"Sicak hava ile soğuk havanin yer değiş̧tirmesi sonucu meydana gelen hava olayl"

"Saatte kaç km hızla esen hava olayıdır" (Ö46).

Gelgit kavramına ilişkin öğretmen adaylarının çoğunluğu sınırlı algılama (\%36.7) kategorisinde cevap vermişlerdir. Öğretmen adaylarının \%33.3'ünün yanlış algılama, \%26.7'sinin cevapsız \%3.3'ünün doğru algılama kategorisinde cevap verdiği görülmüştür. Gelgit kavramı da yıldız kavramı gibi yalnız iki öğretmen adayının doğru 
cevap verdiği kavram olarak ortaya çıkmıştır. Cevapsız ve yanlış algılama kategorisinde toplam \%60 gibi bir oran olduğu görülmüştür.

Öğretmen adaylarının gelgit ile ilgili bazı örnek ifadeleri: (Ö17).

"Deniz klyılarında dalgaların kıylya gelip gitmesi salınım hareketler yapması olayı"

“Denizdeki sıcak soğuk akıntı” (Ö38).

Ova kavramına sosyal bilgiler öğretmen adaylarının çoğunluğunun (\%31.7) cevap vermediği görülmektedir. Öğretmen adaylarının \%28.3'ünün sınırlı algılama, doğru algılama \% 25'inin, \%15'inin yanlış kategorisinde cevap verdiği görülmüştür. Sınırlı algılama ve doğru algilama kategorisinde toplam \%53.3 gibi bir oran olduğu görülmüştür.

Öğretmen adaylarının ova ile ilgili bazı örnek ifadeleri:

"Düz ve kuru alanlara verilen isimdir" (Ö3).

“Köylerin kurulduğu alanlara denir" (Ö58).

Yayla kavramına öğretmen adaylarının çoğunluğu sınırlı algılama (\%38.3) kategorisinde cevap vermişlerdir. Öğretmen adaylarının \%33.3'ünün doğru algılama, \%21.7'sinin cevapsız, \%6.7'sinin yanlış algılama kategorisinde cevap verdiği görülmüştür. Doğru algılama ve sınırlı algılama kategorisinde toplam \%71.6 gibi bir oran olduğu ortaya çıkmıştır.

Öğretmen adaylarının yayla ile ilgili bazı örnek ifadeleri:

"Insanların tarım, hayvancılık, turizm ya da ticari amaçlı olarak geçici süreliğine kullandıkları yerleşmelerdir" (Ö1).

"Yeşil alanlara verilen isimdir" (Ö36)

4.Sosyal bilgiler öğretmen adaylarının seçilen şarkı sözlerinde geçen coğrafya kavramlarına yönelik kavram yanılgıları nelerdir?

Sosyal bilgiler öğretmen adaylarının seçilen şarkı sözlerinde geçen coğrafya kavramlarına yönelik kavram yanılgılarını ortaya koymak için öğretmen adaylarının kavramlara ilişkin verdiği cevaplarda cümlelerinde başka bir kavramı doğru bir şekilde tanımladıkları cevaplar değerlendirmeye alınarak aşağıdaki tabloda gösterilmiştir (Tablo 5).

Tablo 5. Sosyal Bilgiler Öğretmen Adaylarının Kavram Yanılgıları

\begin{tabular}{llll}
\hline Kavramlar & Kavram yanılgısı & Toplam \\
\hline Kıră̆ı & $\begin{array}{l}\text { Kırç (7), çiğ (5), yağmur (4), donlu gün (3), } \\
\text { kar (1) }\end{array}$ & f 20 \\
Karadelik & $\begin{array}{l}\text { Maar (2), galaksi (1) uzay (1), kütle çekimi } \\
\text { (1), jeosenklinal (1), galaksi (1), krater (1) }\end{array}$ & f & \\
& Hava durumu (10), sıcaklık (2), rüzgâr (2), & f & \multicolumn{2}{c}{17} \\
İklim & iklim faktörü (2), mevsim (1) & f 6
\end{tabular}




\begin{tabular}{|c|c|c|c|}
\hline Eksen & $\begin{array}{l}\text { Ekvator (7), paralel (6), yörünge (4), enlem } \\
(2) \text {, yalpa hareketi (1), günlük hareket( } 1)\end{array}$ & $\mathrm{f}$ & 21 \\
\hline Büyükşehir & İl (2), metropol (1), şehir (1) & $\mathrm{f}$ & 4 \\
\hline Krater & $\begin{array}{l}\text { Volkan bacası (3), göl (1), piroklastik } \\
\text { madde (1), geçirimli taş (1), lav (1), fay (1) }\end{array}$ & $\mathrm{f}$ & 8 \\
\hline Güneş Tutulması & Ay tutulması (5) & $\mathrm{f}$ & 5 \\
\hline Ay Tutulması & Güneş tutulması (7) & $\mathrm{f}$ & 7 \\
\hline Ada & Yarımada (2) & $\mathrm{f}$ & 2 \\
\hline Yıldız & Gezegen (9), göktaş1 (7), meteor (4) & $\mathrm{f}$ & 20 \\
\hline Şehir & il (4), kasaba (3), yerleşme (1) & $\mathrm{f}$ & 8 \\
\hline Rüzgâr & Cephe (3), rüzgâr hızı (1) & f & 4 \\
\hline Gelgit & Dalga (8), akıntı (2) & f & 10 \\
\hline Ova & Plato (5), geçici yerleşme (1) & f & 6 \\
\hline Yayla & Mezra (1) & $\mathrm{f}$ & 1 \\
\hline
\end{tabular}

Tablo 5 incelendiğinde sosyal bilgiler öğretmen adaylarının araştırmaya dahil olan 16 kavramın hepsine yönelik olarak kavram yanılgılarına sahip oldukları görülmektedir. Diğer bir deyişle, her kavram az ya da çok başka bir kavram yerine kullanılmıştır. Tablo incelendiğinde karadelik kavramının çok sayıda kavram yerine yanlış olarak kullanıldığı görülmüştür. Karadelik en fazla farklı kavramla açıklanan yanılgının olduğu kavram olarak ortaya çıkmıştır. Karadelik 7 kavram ile karıştırılmıştır. Bu kavramlar maar, galaksi, uzay, kütle çekimi, jeosenklinal, galaksi, kraterdir. Sosyal bilgiler öğretmen adaylarının en fazla kavram yanılgısına sahip olduğu kavramlar ise sırasıyla eksen $(\mathrm{f}=21)$, kırağ $1(\mathrm{f}=20)$, yıldız $(\mathrm{f}=20)$ ve iklim $(\mathrm{f}=17)$ kavramlarıdır.

Eksen kavramı en çok ekvator ( $\mathrm{f}=7)$ kavramıyla karıştırılmıştır. Yine sırasıyla paralel, yörünge, enlem, yalpa hareketi, günlük hareket kavramlarıyla karıştırıldığı görülmüştür. Kırağı kavramı da en çok kırç (f=7) kavramıyla karıştırılmıştır. Yine öğretmen adaylarının kırağıyı sırasıyla çiğ, yağmur, donlu gün, kar kavramlarıyla karıştırdığı görülmüştür. Yıldız kavramı en çok gezegen (f=9) kavramıyla karıştırılmıştır. Yine göktaşı ve meteor karıştırıldığı diğer kavramlar olarak ortaya çıkmıştır. İklim ise en çok hava durumu $(\mathrm{f}=10)$ kavramıyla karıştırılmıştır. Sıcaklık, rüzgâr, iklim faktörü, mevsim karıştırıldığı diğer kavramlar olmuştur. 
Gelgit en çok dalga $(\mathrm{f}=8)$ ile karıştııılmış yine akıntı kavramıyla da karıştırıldı̆̆ 1 görülmüştür. Krater en çok volkan bacasıyla $(\mathrm{f}=3)$ karıştırılmıştır. Yine göl, piroklastik madde, geçirimli taş, lav, fay kraterle karıştırılan kavramlar olarak ortaya çıkmışıır. Şehir kavramının en çok il kavramıyla ( $\mathrm{f}=10$ ) ayrıca kasaba ve yerleşme kavramlarıyla karıştırıldıkları görülmüştür. Rüzgâr en fazla cephe kavramıyla (f=3) yine rüzgâr hızıyla karıştırılırken ova en çok platoyla $(\mathrm{f}=5)$ daha sonra geçici yerleşmeyle karıştırılmıştır. Öğretmen adaylarının sıcaklığı 1sı ile güneş ve ay tutulmasını birbiriyle, adayı yarımadayla, yaylayı mezrayla karıştırdıkları görülmektedir.

\section{Tartışma Sonuç ve Öneriler}

$\mathrm{Bu}$ çalışmada öğretmen olduklarında coğrafya öğretecek sosyal bilgiler öğretmen adaylarının ister istemez gündelik hayatlarının bir parçası olan müzikten yola çıkarak çalışma için seçilen şarkı sözlerindeki coğrafya kavramlarını anlama düzeyleri ve kavram yanılgıları belirlenmeye çalışılmıştır. Buna göre, öğretmen adaylarının çoğunluğunun Buz Kırağı, Yalnız Çiçek, Delikanlım, Heyecanı Yok, Şehrin Yolu, Tarifi Zor, Bu Dünya Yalan şarkılarını defalarca dinlediği, Buz Kırağı, Aşk Bitsin, Yalnız Çiçek, Delikanlım, Heyecanı Yok, Şehrin Yolu, Tarifi Zor, Bu Dünya Yalan şarkılarının sözleri bildikleri ortaya çıkmıştır. Dolayısıyla öğretmen adayları bu şarkı sözlerinde geçen coğrafya kavramlarını kendileri şarkıları mırıldanırken veya şarkılara eşlik ederken kullanmaktadırlar. Örneğin sözlerini bildikleri şarkı sözlerinde geçen kırağı, iklim, sıcaklık, eksen, güneş tutulması, ay tutulması, şehir, rüzgâr, yayla kavramlarını şarkılarla birlikte dile getirmiş oldukları görülmektedir. Yani öğretmen adayları çalışma kapsamında yer alan şarkı sözlerindeki coğrafya kavramlarını duyuyorlar ve telaffuz ediyorlar diye düşünülebilir.

Öğretmenlerin amacının derslerinde terim ve kavram ezberletmek olmadı̆̆ 1 söylenebilir. Ancak defalarca dinlediği, diline dolanmış bir şarkıda duyduğu cümlelerde geçen bir terimi fark etmemek, söylediği terimi bilmemek, bilmiyorsa merak edip araştırmamak öğretmen adaylarının aldıkları coğrafya eğitiminin gerçek amacına ulaşmadığının da bir göstergesidir. Çünkü coğrafya eğitiminde merak etme, sorgulama, problem çözme ve yorum yapma kazandırılmak istenen becerilerdendir. Dolayısıyla öğrencilerine coğrafi bilgi öğretecek öğretmen adaylarından da gündelik hayatlarında maruz kaldıkları bilgileri keşfetmeleri beklenmektedir.

Öğretmen adaylarının az ya da çok şarkı sözlerinde duydukları ve bildikleri coğrafya kavramlarını anlama düzeyleri incelendiğinde pek çok kavramı doğru bilmedikleri ve hepsine ait kavram yanılgıları olduğu belirlenmiştir. Öğretmen adaylarının kavramları algılama düzeyi incelendiğinde ise doğru algılama kategorisinde en yüksek paya sahip üç kavram sırasıyla şehir, güneş tutulması, ada kavramlarının olduğu belirlenmiştir. $\mathrm{Bu}$ kavramlardan şehir ve ada kavramının gündelik hayatta fazla kullanılan birer kavram olmasının etkisinin olduğu düşünülebilir. Doğru algılama kategorisinde en az paya sahip kavramların ise sırasıyla eksen, karadelik ve sıcaklık olduğu ortaya çıkmıştır.

Tüm cevaplar içerisinde doğru anlaşılan ve sınırlı anlaşılan kavramlar değerlendirildiğinde ise öğretmen adaylarının en fazla yayla kavramını anladıkları ortaya çıkmıştır. Eksen kavramı ise en az anlaşılan kavram olarak ortaya çıkmıştır. Eksen 
kavramı aynı zamanda öğretmen adaylarının en fazla cevapsız bıraktıkları kavram olmuştur. Gülüm'ün (2010) Sosyal Bilgiler öğretmen adaylarıyla yürüttüğü çalışmasında "Eksen eğikliği nedir? Açıklayınız", şeklindeki sorusuna yalnızca katılımcıların \%14'ü tam anlama grubuna giren cevaplar verebilmiş. \% 29'unun ise kavram yanılgısına sahip olduğu belirlenmiştir. Çalışmamızda eksene verilen cevapların Gülüm'ün (2010) çalışmasında eksen eğikliğine verilen cevaplar ile benzer olduğu buna göre sosyal bilgiler öğretmen adaylarının hem eksen hem de onunla bağlantılı eksen eğikliği gibi kavramları tam olarak anlayamadıkları söylenebilir.

Sosyal bilgiler öğretmen adaylarının yanlış algılama kategorisinde en fazla paya sahip olan ilk üç kavram sırasıyla yıldız, büyükşehir ve iklim kavramlarıdır. Öğretmen adaylarının gündelik hayatlarında sıklıkla karşılaşabilecekleri bu kavramları başka kavramlarla karıştırarak açıklamaları bu kavramlara ilişkin bilimsel doğruları bilmedikleri görülmektedir. En fazla cevapsız bıraktıkları ilk üç kavram ise eksen, karadelik ve sıcaklık kavramlarıdır.

Sosyal bilgiler öğretmen adaylarının kavram yanılgıları incelendiğinde ise en fazla yanlış kavramla açıkladıkları kavramın karadelik olduğu görülmüştür. Karadelik maar, galaksi, uzay, kütle çekimi, jeosenklinal, galaksi, kraterden oluşan 7 ayrı kavramla karıştırılmıştır. Sosyal bilgiler öğretmen adaylarının en fazla karıştırdıkları kavramlar ise sırasıyla eksen, kırağı, yıldız ve iklim kavramlarıdır. Eksen en çok ekvator kavramıyla karıştırılmıştır. Yine sırasıyla paralel, yörünge, enlem, yalpa hareketi, günlük hareket kavramlarıyla karıştırıldığı görülmüştür. Kırağı kavramı da en çok kırç kavramıyla karıştırılmıştır. Yıldız kavramı en çok gezegen kavramıyla karıştırılmıştır. Yine göktaşı ve meteor karıştırıldığı diğer kavramlar olarak ortaya çıkmıştır. Balcı'nın (2018) 65 yaş ve üstü, 21-32 yaş 23 kişiyle hayat hikâyelerindeki coğrafi bilgi içeren söylemlerini incelediği çalışmasında katılımcıların kutup yıldızı kavramının kullanımında yanılgıya düştükleri belirlenmiştir. İmsak vaktinde doğan bir gök cismi için katılımcı kutup yıldızı ifadesini kullanmıştır. İklim ise en çok hava durumu kavramıyla karıştırılmıştır. Sıcaklık, rüzgâr, iklim faktörü, mevsim iklim yerine kullanılan diğer kavramlar olmuştur. Alım vd. (2005) çalışmalarında 5. Sınıf öğrencileriyle gerçekleştirdikleri öğrencilerin iklimi mevsim, hava durumu, sıcaklık, yer şekilleri, bitki örtüsü, doğal afet ve ova gibi kavramlarla karıştırdıklarını ortaya çıkarmışlardır. Kavram yanılgılarının tespit edildiği benzer çalışmalarda da (Başıbüyük vd., 2004; Alım vd., 2008; Pınar ve Akdağ, 2012, Demirkaya ve Karacan, 2016) öğrencilerin iklim kavramıyla ilgili kavram yanılgılarına sahip oldukları ortaya çıkarılmıştır. Yine gelgit kavramının da dalga ve akıntı kavramıyla karıştırıldığ1 görülmüştür. Gümüş ve Avcı (2006) 6. sınıf öğrencilerinin sosyal bilgiler dersindeki coğrafi kavramları anlama düzeylerini belirleyip sahip oldukları coğrafi kavram yanılgılarını ortaya koymuştur. Buna göre gel git kavramı ile ilgili olarak yöneltilen soruya öğrencilerin büyük bir çoğunluğunun $(\% 55,8)$ doğru algılama kategorisine giren cevaplar verdikleri görülmüştür.

Krater en çok volkan bacasıyla karıştırılmıştır. Yine göl, piroklastik madde, geçirimli taş, lav, fay kraterle karıştırılan kavramlar olarak ortaya çıkmıştır. Şehir kavramı en çok il kavramıla, rüzgâr en fazla cephe kavramıyla, ova ise en çok plato kavramıyla karıştırılmıştır. Alım vd. (2005) çalışmalarında 5. sınıf öğrencilerinin ovayı, plato, oba, 
krater gibi kavramlarla karıştırdıklarını ortaya çıkarmışlardır. Sosyal bilgiler öğretmen adaylarının da sıcaklık kavramını 1sı kavramıyla karıştırdığı ortaya çıkarılmışıtır. Aydoğan vd. (2003) 277'si üniversite ve 740'ı lise öğrencisi olmak üzere toplam 1017 öğrenciye uyguladıkları çalı̧̧mada öğrencilerin isı ve sıcaklık konusunda kavram yanılgılarına sahip olup olmadığını tespit etmeye ve kavram yanılgılarını belirleye çalışmışlardır. Öğrencilerin, çoğunlukla 1sı ve sıcaklık kavramlarını birbirine karıştırdığı sıcaklığı da 1sı gibi bir tür enerji olarak düşündükleri ortaya çıkmıştır. Yine Pınar ve Akdağ (2012) sosyal bilgiler öğretmen adaylarının sıcaklıkla ilgili kavram yanılgılarının olduğunu tespit etmiştir. Öğrencilerin, çoğunlukla ısı ve sıcaklık kavramlarını birbirine karıştırmış, sıcaklığı da 1sı gibi bir tür enerji olarak düşündükleri ortaya çıkmıştır.

Araştırma bulgu ve sonuçlarına göre öneriler şunlardır;

- Coğrafya öğretiminde kavramlar öğretilirken şarkı sözlerindeki kavramlar örnek olarak verilebilir.

- Sosyal bilgiler öğretmen adaylarına bilmediği terim ve kavramlar için bir başvuru kaynağı olarak kullanabilecekleri Coğrafya Terimleri Sözlüğü edinmeleri sağlanabilir.

- Nasıl daha iyi öğretebilirim, yeni teknolojileri hangi konu ve derslerime adapte edebilirim diye düşünmesi beklenen öğretmen adaylarının alan bilgisinden yoksun olması düşünülemez. Bu yüzden üniversite yıllarında pedagojik bilgiyle birlikte alan bilgisi de ihmal edilmemelidir.

- Öğretmen adaylarının bilgi ve kavram yanılgılarını mezun olmadan düzeltmeye çalışması sağlanmalı, gerekirse öğrenci ihtiyaçlarına göre seçmeli dersler eklenmelidir.

- Bilindiği gibi coğrafyadaki konular birbiriyle bağlantılıdır. Dolayısıyla temel olan çeşitli konularda kavram yanılgısı varsa bunlar tespit edilmeli, düzeltilmeli, tam öğrenmeden sonra diğer konuya geçilmelidir.

- Üniversite eğitim fakülteleri ve milli eğitim müdürlükleri işbirliği ile kavramlarla ilgili çalışmaların olduğu bilimsel çalışmalar öğretmen adaylarıyla ve öğretmenlerle bilimsel yayın paylaşım günleri olarak çeşitli tarihlerde paylaşılabilir.

\section{Kaynaklar}

Alkış, S. (2005). İlköğretim birinci kademe sosyal bilgiler ders kitaplarında coğrafya konularıyla ilgili kavramların belirlenmesi (2004 programına göre). Marmara Coğrafya Dergisi, 11, 83-92.

Alkış, S. (2006). İlköğretim öğrencilerinin yağış kavramını algılama biçimleri. İlkögretim Online, 5(2), 126-140.

Akengin, H. ve Süer, S. (2011). Coğrafi kavramlar bakımından öğrencilerin hazırbulunuşluk düzeyleri ve bu kavramların geliştirilmesi üzerine deneysel bir araştırma. Marmara Coğrafya Dergisi, 24, 26-48.

Akış, A. ve Kaya, B. (2018). Coğrafya 4. sınıf ögrencilerinin "kuraklık" kavramıyla ilgili bilişsel yapılarının belirlenmesi. International Journal of Geography and Geography Education, 38, 58-68. https://doi.org/10.32003/iggei.440900 
Alım, M., Özdemir, Ü. ve Yılar, B. (2008). 5. sınıf öğrencilerinin bazı coğrafya kavramlarını anlama düzeyleri ve kavram yanılgıları. Atatürk Üniversitesi Sosyal Bilimler Enstitüsü Dergisi, 11(1), 152-162.

Ançel, G. (2018). Aşk Bitsin [Buray]. Kehanet [CD] içinde, İstanbul: Sony Music.

Aydoğan, S., Güneş, B. ve Gülçiçek, Ç. (2003). Isı ve sicaklık konusunda kavram yanılgıları. Gazi Eğitim Fakültesi Dergisi, 23(2), 111-124.

Balc1, A. (2018). Hayat hikâyelerindeki coğrafi bilgi. International Journal of Geography and Geography Education, 38, 40-57. https://doi.org/10.32003/iggei.439294

Bedir, G. ve Akkurt, A. (2013). Şarkılarla coğrafya öğretimi. Doğu Coğrafya Dergisi, 12(28), 303-316.

Başıüyük, A., Doğar, Ç., Gürses, A. ve Yazıcı, H., (2004). Yükseköğrenim ögrencilerinin hava ve iklim olaylarını anlama seviyeleri ve kavram yanılgıları. Milli Ĕ̆itim Dergisi, 162, 144-160.

Bozkurt, O. ve Cansüngü, Ö. (2002). İlköğretim öğrencilerinin çevre eğitiminde sera etkisi ile ilgili kavram yanılgıları. Hacettepe Üniversitesi Ĕ̆itim Fakültesi Dergisi, 23, 67-73.

Bozyiğit, R. ve Kaya, B. (2017). Coğrafya öğretmen adaylarının doğal afetlerle ilgili bazı kavramlar hakkındaki bilişsel yapılarının belirlenmesi. Marmara Coğrafya Dergisi, 35, 55-67. https://doi.org/10.14781/mcd.291146

Buray (2019, Mart 29). Aşk Bitsin [Video]. Youtube. https://www.youtube.com/watch?v=i6Zr-sSQOpM

Canfeza (2018, Aralk 15). Dem [Video]. Youtube. https://www.youtube.com/watch?v=mXH3Q1Qm_m0

Cin, M. (2010). Sınıf öğretmeni adaylarının doğal afetler ile ilgili yanılgıları. Marmara Coğrafya Dergisi, 22, 70-81.

Coşkun, M. (2003). Coğrafya öğretiminde nem konusundaki kavram yanlışlıkları ve giderilmesine yönelik öneriler. Gazi Ĕ̆itim Fakültesi Dergisi, 23(3), 147-158.

Çetin, E., Kurnaz, M. Ö. ve Çağlar, A. (2021, Ekim). 4. ve 5. sınıf sosyal bilgiler ders kitaplarındaki coğrafya kavramları. III. Uluslararası Coğrafya Eğitimi Kongresi'nde sunulan bildiri. Sivas Cumhuriyet Üniversitesi.

Demirkaya, H. ve Karacan, H. (2016). Ortaokul 6. sınıf öğrencilerinin sosyal bilgiler dersindeki bazı coğrafi kavramları anlama düzeyleri ve kavram yanılgıları. International Journal of Field Education, 2(2), 38-57.

Doğanay, H. (2005). Coğrafya'ya giriş, genel ve fizikî coğrafya (9. Baskı). Aktif Yayınevi.

Doğulu, K., Uzer, B. Ve Turgut, O. (2018). Issız Ada [Kenan Doğulu]. Vay Be [CD] içinde, İstanbul, Doğulu Production.

Ertaş, E. (2019). Coğrafya ĕgitiminde ortaöğretim öğrencilerinin bölge kavramını anlama düzeyleri ve kavram yanılgıları [Yayımlanmamış Yüksek Lisans Tezi]. Marmara Üniversitesi.

Gazapizm (2017) Heyecanı yok. Heyecanı Yok [CD] içinde, İzmir: Argo İzmir.

Gençoğlu, S. (2012). Gözlerine Teslimim. Joker [CD] içinde, İstanbul: Sony Music. 
Gümüş, N. ve Avcı, G. (2016). Altıncı sınıflarda sosyal bilgiler dersinde öğrencilerin coğrafi kavramları anlama düzeyleri ve kavram yanılgılarının belirlenmesi. The Journal of Academic Social Science Studies, 47, 191-206.

Gülüm, K. (2010). Sosyal bilgiler öğretmenliği öğrencilerinin fiziki coğrafya konularındaki bazı temel kavramları anlama düzeyi ve kavram yanılgıları. Akademik Bakış Dergisi, 20, 1-7.

Güngördü, E. (2006). Eğitim fakülteleri için coğrafya öğretim yöntemleri ve çağdaş ögretim yaklaşımları ilkeler-uygulamalar. Asil Yayın Dağıtım.

Karasar, N. (1998). Bilimsel Araştırma Yöntemi Kavramlar, Illkeler, Teknikler. Nobel Yayınlar1.

Kaya, B. ve Bozyiğit, R. (2019). Coğrafya öğretmen adaylarının coğrafya kavramı üzerine düşünceleri. International Journal of Geography and Geography Education, 39, 55-69. https://doi.org/10.32003/iggei.518935

Kayacan, Z. (2010). Illköğretim altıncı sınıf öğrencilerinin coğrafi koordinatlarla ilgili kavram yanılgıları [Yayımlanmamış Yüksek Lisans Tezi]. Balıkesir Üniversitesi.

Kuzey, M. ve Değirmenci, Y. (2019). Sosyal bilgiler öğretmen adaylarının harita ve yön okuryazarlığına ilişkin kavramları anlama düzeyleri ve kavram yanılgıları. Milli Ĕ̆itim Dergisi, 48(223), 207-230.

Kızılçaoğlu, A. (2009). Ortaöğretim öğrencilerinin bakı kavramını anlama düzeyi ve kavram yanılg1ları. E-Journal of New World Sciences Academy, 4(1), 99-114.

Özarslan, Ersin (2010). Şiirden coğrafyaya-Arif Nihat Asya'nın şiirlerinde mekân endişesi. Ötüken Neşriyat.

Özden, Ö. (2010), Üniversite ögrrencilerinin popüler kültür ve popüler müzikle ilgili görüşleri [Yayımlanmamış Doktora Tezi]. Selçuk Üniversitesi.

Paker, K.O. (2008). Popüler müzik, günlük ideoloji ve benlik inşaası: Sezen Aksu şarkıları üzerinden bir inceleme. İstanbul Üniversitesi İletişim Fakültesi Dergisi, 34, 87-106.

Pınar, A. ve Akdağ, H. (2012). Sosyal bilgiler öğretmen adaylarının iklim, rüzgar, sıcaklık, yağış, erozyon, ekoloji ve harita kavramlarını anlama düzeyi. Illkögretim Online, 11(2), 530-542.

Sarıkabadayı, S. (2018). Tarifi Zor. Boza Boza [CD] içinde, İstanbul: Pdnd Müzik.

Sever, R. (2005). Coğrafya öğretim programlarında doğal mevsim kavramı. Doğu Coğrafya Dergisi, 13, 117-133.

Şehrazat (2018). Büyük Delilik [Nil Özalp]. Büyük Delilik [CD] içinde, İstanbul: Avrupa Müzik.

Şimşek, Y. (2018). Cahit Külebi şiirlerinde mekânın poetikası. Uluslararası Sosyal Araştırmalar Dergisi, 11(60), 185-198. http://dx.doi.org/10.17719/jisr.2018.2774

Tilbe, Y. (1994). Delikanlım [Gülşen].Yıldız Tilbe'nin Yıldızlı Şarkıları [CD] içinde, İstanbul: Özdemir Plak, 2018.

Tilbe, Y. (1994). Yalnız Çiçek [Aleyna Tilki].Yıldız Tilbe'nin Yıldızlı Şarkıları [CD] içinde, İstanbul: Özdemir Plak, 2018.

Tilbe, Y. (1995). Buz kırağı [Edis Görgülü].Yıldız Tilbe'nin Yıldızlı Şarkıları, Vol. 2 [CD] içinde, İstanbul: Özdemir Plak, 2018. 
Tilbe, Y. (1995). Arzular Arsız [İlyas Yalçıntaş].Yıldız Tilbe ’nin Yıldızlı Şarkıları [CD] içinde, İstanbul: Özdemir Plak, 2018.

Tilbe, Y. (1996). Dili Ballım [Zara].Yıldız Tilbe'nin Yıldızlı Şarkıları [CD] içinde, İstanbul: Özdemir Plak, 2018.

Turan, İ. (2002). Lise coğrafya derslerinde kavram ve terim öğretimi ile ilgili sorunlar. Gazi Ĕ̈itim Fakültesi Dergisi, 22(2), 67-84.

Uçan, A. (1994). Müzik eğitimi temel kavramlar-ilkeler- yaklaşımlar. Müzik Ansiklopedisi Yayınları.

Yalçıntaş, İ. (2018). Şehrin Yolu [Feride Hilal Akın-İlyas Yalçıntaş]. Şehrin Yolu [CD] içinde, İstanbul, Doğan Müzik Company.

Yıldırım, A. ve Şimşek, H. (2013). Sosyal bilimlerde nitel araştırma yöntemleri. Seçkin Yayıncilik.

Yıldırım, B. (1994). Şiir-mekân ilişkisi ve Edip Cansever. Ege Mimarlık Dergisi, 14, 5051.

Yıldı,, G. (2006). Illköğretimde müzik ögretimi, (2.Baskı). Anı Yayıncılık.

Yılmaz, E. B. (2017). İlhan Geçer Şiirinde Mekân-İnsan İlişkisi. Türk Dili, 792, 123 135.

Yivli, O. (2009). Yahya Kemal'in şiirinde mekân. Türk Dili, 696, 680-694. 